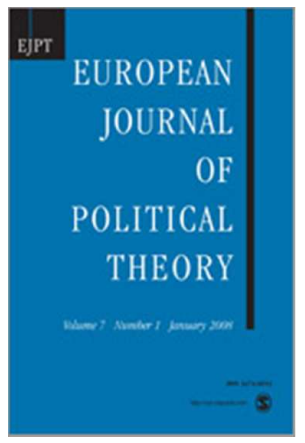

\title{
Wollstonecraft and the Political Value of Contempt
}

\begin{tabular}{|c|l|}
\hline Journal: & European Journal of Political Theory \\
\hline Manuscript ID: & EJPT-15-0046.R2 \\
\hline Kanuscript Type: & Original Article \\
\hline Keywords: & Wollstonecraft, contempt, Burke, ridicule, dignity \\
\hline & $\begin{array}{l}\text { In her Vindication of the Rights of Men Mary Wollstonecraft accused } \\
\text { Edmund Burke of having contempt for his political opponents. Yet she } \\
\text { herself expressed contempt for Burke and did so unapologetically. Readers } \\
\text { have long regarded Wollstonecraft's decision to match Burke's contempt } \\
\text { with one of her own as either a tactical blunder or evidence that she } \\
\text { sought merely to ridicule Burke rather than argue with him. I offer an } \\
\text { interpretation and defense of Wollstonecraft's rhetorical choices by } \\
\text { situating the Vindication within eighteenth-century debates about the } \\
\text { dangers of elite contempt and the best methods for stifling it. Rather than } \\
\text { countering Burke's contempt with more of the same, I argue, } \\
\text { Wollstonecraft's Vindication marks a distinction between two forms of } \\
\text { contempt. The first expresses the false sense of superiority experienced } \\
\text { by elites who owe their social elevation to arbitrary differences of wealth or } \\
\text { family. As such, it represents both an abuse of privilege and an anxious } \\
\text { recognition among elites that their claims to dignity may be unfounded. By } \\
\text { contrast, the contempt Wollstonecraft directs at Burke represents a } \\
\text { dignified withdrawal of esteem which signals that one's opponent is } \\
\text { unworthy of the dignity to which they lay claim. If Wollstonecraft appeared } \\
\text { to treat Burke abusively it was because she came to consider this second } \\
\text { form of contempt as an antidote to the abusive contempt of the privileged. } \\
\text { I conclude by spelling out some implications of Wollstonecraft's analysis of } \\
\text { contempt for recent debates in political theory over the importance of } \\
\text { dignity to democracy. }\end{array}$ \\
\hline \hline
\end{tabular}

\section{SCHOLARONE}

Manuscripts 
60 


\section{Wollstonecraft and the Political Value of Contempt}

In the dramatic opening to her Vindication of the Rights of Men, Mary Wollstonecraft accused Edmund Burke of passing off ridicule as a 'test of truth' in his Reflections on the Revolution in France (1989, V: 9). ${ }^{\mathrm{i}}$ Far from leading his readers towards truth, she contended, Burke's ridicule was motivated by, and designed to elicit, nothing but contempt. The objects of that contempt, in Wollstonecraft's eyes, ranged from the poor, to the dissenting minister Richard Price (whose sermon welcoming the revolution had served as the catalyst for Burke's polemic), to the members of the Assemblée Nationale itself. ${ }^{\text {ii }}$ Burke's repeated attempts to raise a 'horse laugh,' Wollstonecraft suggested, had far more to do with despising his opponents as unworthy than with proving the truth of any claim (1989, V: 7). ${ }^{\text {iii }}$

Yet, as several readers of the Vindication have pointed out, Wollstonecraft's attack on Burke is itself laced with contempt, a contempt often expressed through ridicule. Time and again she heaps mock pity on Burke's 'infantile sensibility,' pleading that she must handle him delicately for fear that an overly rigorous debate on a 'metaphysical' topic like the rights of man would 'derange' his 'nervous system' (1989, V: 58 and 16). ${ }^{\text {iv }}$ This was a contempt, moreover, that she openly declared rather than insinuated. The Vindication mimicked the epistle form of Burke's Reflections, with Burke himself standing in as the letter's addressee. But in sharp contrast to the warm opening salutation with which Burke greeted Charles-Jean-Francois Depont (his correspondent in Reflections), the Vindication's greeting placed Burke firmly on guard. In what follows, Wollstonecraft warned, she will not only 'express contempt' for Burke but will do so overtly, rather than concealing her feelings as the 'equivocal idiom of politeness recommends' (1989, V: 7). 
How are we to make sense of Wollstonecraft's upbraiding of Burke for expressing contempt, on the one hand, and her unapologetic determination to do precisely the same towards him, on the other? And what might answering this question reveal about the place of contempt within her political project in the early 1790s? From the moment of its publication a matter of weeks after Burke's Reflections both sympathetic and hostile readers of the Vindication have agreed that Wollstonecraft erred by choosing to match Burke's contempt with one of her own. A generous early critic in the English Review drew parallels between the Vindication's mode of attack and that of the Reflections, and worried that Wollstonecraft would be accused of having 'repaid' Burke too much 'in his own coin' (Anon., 1791b: 95). William Godwin, who in his own much earlier engagement with Burke had been careful to combine criticism of his 'principles' with respect for Burke's character, called the work 'too contemptuous and intemperate' (1798: 76). ${ }^{\mathrm{v}}$ More recent critics have concurred. ${ }^{\mathrm{vi}}$ Janet Todd even found something of a doublestandard at work in Wollstonecraft's criticism of Burke's 'sarcasms,' suggesting that 'Burke's attack on Price never stoops to the kind of personal abuse that Wollstonecraft levels at Burke' (Wollstonecraft, 1993: Editor's note 45). At best, it would seem, Wollstonecraft's contempt for Burke distracted from her arguments for the rights of man and her defense of the revolutionary cause. At worst, it revealed her to have been an injudicious or even wantonly abusive critic.

These criticisms of the Vindication, I aim to show, posit a misleading equivalence between Wollstonecraft's and Burke's modes of address and in so doing occlude the central role played by a particular understanding of contempt in Wollstonecraft's vision of an egalitarian social order. For Wollstonecraft's eighteenth-century readers, to 'contemn' someone was to disdainfully regard them as inferior in status or, worse, dismiss them as unworthy of regard at all. ${ }^{\mathrm{vii}}$ As such, contempt most usually expressed and solidified social hierarchies to the benefit of 
the elites at their summit. ${ }^{\text {vii }}$ In responding to Burke the way she did, I argue, Wollstonecraft contested this understanding and called attention to contempt's ambiguous relationship to social inequality. Far from countering Burke's contempt with an equal or harsher dose of the same, I maintain, Wollstonecraft's Vindication instead marked a distinction between two forms of contempt. The first, exemplified by Burke's attack on the poor, expressed the false sense of superiority experienced by those who owe their social elevation to arbitrary differences of wealth or family. What is special about this form of contempt, as Wollstonecraft analyzed it, is that it represented both an abuse of social privilege and an anxious recognition among elites that their claims to esteem are ultimately unfounded.

By contrast, in her response to Burke, Wollstonecraft strove to express a different sort of contempt, one grounded in the conscious dignity of an independent political agent. Those trained to express this form of contempt will not be cowed by elite insolence and will prove capable of the kind of self-assertion Wollstonecraft deemed vital to social and political freedom. If Wollstonecraft neglected to treat Burke civilly or examine his arguments closely, I further claim, it was because she came to consider this dignified contempt as itself an antidote to the abusive yet anxiety-ridden contempt of the privileged. Though never shedding some early reservations about contempt entirely, Wollstonecraft came in the 1790 s to recognize its value as a form of 'active non-identification,' that is, a way of signaling to oneself and one's audience that an opponent is unworthy of the dignity to which they lay claim. ${ }^{\text {ix }}$

I develop this argument in four stages. First, I show how many of the moral philosophers, advice book authors, and educational theorists who influenced Wollstonecraft took issue with the habitual contempt shown by the socially privileged towards, in particular, domestic servants and the laboring poor. Two principal strategies for countering this behavior emerge from this 
literature. For the likes of John Locke and James Burgh, such upper class contempt could best be quelled by inculcating habits of civility and self-restraint among the children of the rich from a young age. Others, however, such as Hester Chapone, proposed that contempt, far from being an abuse only, very often betrayed profound psychic insecurities among the privileged who relied upon it to extract tokens of homage necessary to their fragile self-esteem. A dignified withholding of those tokens, she further implied, could stifle their contempt just as effectively (if not more so) than relying on elites' own self-restraint.

I turn next to Wollstonecraft's own educational program to show how she borrowed from each of these lines of argument. In both her Thoughts on the Education of Daughters and Female Reader, Wollstonecraft proposed that tutors should encourage daughters of the gentry to shun contemptuous habits of speech (particularly ridicule) as needlessly cruel and to regard such habits as signs of dependence and insecurity. I show subsequently how from the early 1790s onwards Wollstonecraft not only deepened this critique of elite behavior but also urged a comprehensive reconsideration of how esteem and contempt should be apportioned in English society more generally. Returning at last to her contest with Burke, I show how Wollstonecraft's understanding of elite contempt as both abusive and anxiety-laden informed her rhetorical choices in attacking Burke's Reflections, choices justified by an argument contained within the Vindication itself. By way of conclusion, I draw out several implications of Wollstonecraft's contempt for recent arguments regarding the indispensability of civic dignity to democratic politics, including in particular the following: that achieving a more egalitarian society may paradoxically require that the socially marginalized learn to consider themselves of superior dignity to those above them in the social order. ${ }^{\mathrm{X}}$ 
I.

What exactly was contempt and what made it so troubling to Wollstonecraft and other social reformers of her day? Contempt, as William Ian Miller remarks, has consistently functioned in modern societies as a 'mechanism' for 'ranking people' (1995: 476). To experience contempt in early modernity was to feel not only an aversion towards someone but also an acute awareness of one's own relative superiority. Crucially, this comparative element separated contempt from other negative passions such as anger or hatred. Thomas Hobbes, in his exhaustive discussion of the passions in Leviathan, was careful to dissociate contempt from hatred, defining it instead as a kind of 'immobility' of the heart experienced by those whose attention had been seized by 'more potent objects' (1991: 39). That which is contemptible, Hobbes suggested, is simply too 'inconsiderable' to stir us much one way or another (1991: 39). This made contempt no less fractious than other, more active passions, however. For humans craving honor, recognition and acknowledgement of their power, to be confronted with 'signs of contempt, or undervaluing' was a grave affront (1991: 88).

If the comparative aspect of contempt was a constant, however, the relevant basis on which the comparison should be made was far less certain. Hobbes had found that those who lack the 'goods which men honor' will invariably be 'contemned' (1840, VI: 466). But what exactly those 'goods' were, or should be, was very much open to debate, especially among those Scottish Enlightenment philosophers who so deeply influenced Wollstonecraft. ${ }^{x i}$ David Hume defined contempt as an alloy of hatred and pride (with the latter preponderant) and although he allowed that strictly speaking anyone could experience this passion, he insisted that the upper classes would have occasion to indulge it far more frequently than the lower because wealth was universally esteemed whereas poverty was shameful. It is difficult for us, he contended, to regard 
members of a different social station with 'indifference'; instead we 'must' feel 'some faint touches' of respect towards the rich and an equal quantity of 'contempt' towards the poor (2003: 252). So strong was this contempt directed towards our social inferiors, in Hume's view, that the rich will strive constantly to 'keep themselves at a distance' from those beneath them on the social spectrum. Indeed, nothing is more alarming to a rich man, he suggested, than the "near approach' of a poor person who fails to acknowledge (or is seemingly unaware) of the discrepancy in rank between them (2003: 253).

Hume's view that poverty would naturally draw contempt was initially seconded by his friend and fellow moral philosopher, Adam Smith. In the first, 1759, edition of The Theory of Moral Sentiments Smith largely agreed with Hume that contempt of the rich for the poor, though certainly regrettable, was nevertheless compelled by nature. In a chapter entitled 'Of the origin of ambition, and of the distinction of ranks,' Smith explained how the miseries of poverty were compounded by the fact that the better off routinely 'turn their eyes away' from the poor and take umbrage if one of them should 'dare' present themselves in their company (2002: 62). Remarkably, Smith presented the poor as only ever experiencing shame rather than resentment at this treatment. Because mankind are disposed to 'sympathize more entirely with our joy than our sorrow,' he stated, we all have a tendency to 'parade' our riches and 'conceal our poverty' as 'mortifying' (2002: 61-2). Only rarely in this early iteration of Smith's treatment of the subject did he suggest that our despising of the poor or our sympathy with the rich could be anything other than natural reflexes. ${ }^{\text {xii }}$

Not everyone, however, was prepared to accept that the contempt of the rich for the poor was natural or inevitable. Even Smith's doubts about the naturalness of elite contempt deepened as he revised The Theory of Moral Sentiments in later years. In a chapter newly added to the 
sixth edition of 1790 , he allowed that the 'disposition to admire, and almost to worship, the rich and the powerful, and to despise [...] persons of a poor and mean condition' might be 'necessary' to 'establish the distinction of ranks' (2002: 72). However, Smith now singled out that 'disposition' as the 'most universal cause of the corruption of our moral senses' (2002: 72). What Hume had presented as a more or less natural compulsion, Smith now saw as an injustice brought about by mankind's fixation with 'wealth and greatness' (2002: 73). While these continue to be valued most, Smith grimly predicted, individuals would be perversely incentivized to avoid the contempt of their peers through accumulating material goods, leaving only 'admirers of wisdom and virtue' to direct contempt towards its 'proper objects,' namely 'vice and folly' (2002: 72-3).

Smith held out little hope that the fundamental realignment of values required to deflect contempt away from the poor would ever occur and offered little advice as to how the corrupting influence of elite contempt could be contained. Authors of educational manuals and conduct books - genres with which Wollstonecraft was deeply familiar, if not always on good terms were far more forthcoming with suggestions. ${ }^{\text {xiii }}$ A basic assumption pervading the education literature in particular was that contempt towards the poor was not a reflection of what human beings naturally considered honorable or despicable, but rather an artificial vice acquired during a corrupted upbringing. John Locke's Some Thoughts Concerning Education and James Burgh's Thoughts on Education (forerunners to Wollstonecraft's own Thoughts on Female Education) stressed the need to counteract the socially learned contempt that the children of the wealthy direct toward those representatives of the poor they most came into contact with, namely domestic servants. Locke regretted that so many children were in the habit of inflicting upon servants 'domineering Words, Names of Contempt, and an imperious Carriage; as if they were of 
another Race, and Species beneath them' and urgently recommended that such behavior be 'weeded out' early by accustoming children to act with 'civility' towards 'meaner sorts of people.' Failure to do so, Locke warned, would eventually result in adults prone to 'Oppression and Cruelty' (1996: 92). Burgh similarly deplored how 'the most laborious, industrious and useful part of mankind' were 'generally treated with neglect and contempt' while 'the idle, the inactive and most useless part of the species, I mean, the rich' were 'adored as Gods upon earth' (1749: 17).

Even if contemptuous attitudes persisted beyond childhood, these critics reasoned, adults could still be trained to exercise self-restraint and conceal their disdain for those they deemed beneath them. This was the view strenuously defended by Godwin in his own contribution to the advice and conduct literature. Against those pretending to 'do homage at the shrine of sincerity' by arguing that hiding disregard for others amounted to hypocrisy, Godwin held that refraining from contemptuous talk was in fact a precondition for frank and open debate among equals (1793a: 272). A true 'freedom of opinion,' he insisted, required not only the absence of legal restraint on thought, but also that a certain 'forebearance' be 'moulded into the manners of the community [sic].' As for the argument that frank expressions of contempt could be used to educate or reform the morally deviant, Godwin was especially scathing towards it: 'Who ever thought,' he asked with ample sarcasm of his own, 'of enlightening his pupil in the truths of geometry $[\ldots]$ by the cool and biting sarcasms of contempt?' (1793a: 275).

If most educational theorists saw contempt as simply abusive, however, others saw in it traces of an anxious dependence or even servility. This argument was advanced with special force by Hester Chapone, an educational theorist whose influence upon Wollstonecraft looms particularly large. ${ }^{\mathrm{xiv}}$ In the fourth of her Letters on the Improvement of the Mind (from which 
Wollstonecraft cited copiously in her Female Reader) Chapone cast serious doubt on Hume's association of contempt with prideful self-satisfaction. Far from expressing a superiority that the proud could take easy pleasure in, Chapone argued, contempt could often reveal deep seated anxieties on the part of the socially privileged. 'Pride,' she begins,

is, I think, an high opinion of one's self, and an affected contempt of others. I say affected, for that it is not a real contempt is evident from this, that the lowest object of it is of importance enough to torture the proud man's heart only by refusing him the homage and admiration he requires....[T]he proud man's contempt of others is only assumed with a view to awe them into a reverence by his pretended superiority, so it does not preclude an extreme inward anxiety about their opinions and a slavish dependence on them for all his gratifications (1786: 59-60).

In this passage contempt is not (or at least not only) an expression of power; it also exposes the uneasy dependence of the person expressing it on the very people he is trying to degrade. Hume, as we have seen, insisted that the contemptuous will want to put themselves at a certain distance from the contemptible. Chapone here offered a refined version of this insight; 'real contempt' will require distance because its object is truly unworthy of attention. Most of what passes for contempt, however, is not of this nature. '[F]eigned contempt' requires that its object be at least close enough to respond with the desired signals of respect. A vain man's 'airs of insolence and contempt,' Chapone went on to write, really only succeeds in displaying just how desperately he 'depend(s) on the breath of the person he would be thought to despise' (1786: 61). To return to Hume's own example, the rich man's alarm is caused not by the mere presence of the poor man, 
but by the latter's failure to signal acknowledgement of his own inferiority. On Chapone's analysis, and against Hume, such alarm reveals the absence of contempt rather than its presence. Real contempt, a contempt thoroughly detached from any desire for recognition, is the preserve, the achievement even, of a truly independent agent.

Notice, however, that Chapone's analysis also suggested an effective method for throwing a puffed up gentleman anxious about his status off balance. Simple refusal of the signs of reverence such a man 'requires' suffices to lay his dependence bare. A tactical form of withholding attention, in other words, could itself be a useful manner of turning the tables on elites and exposing their anxieties. When Wollstonecraft pointedly refused to engage Burke's arguments in the Vindication of the Rights of Men, I will argue below, she used a version of this strategy to puncture the assumed superiority of her adversary. Before turning to the Vindication, however, I look in the beginning of the next section at how Wollstonecraft developed her own analysis of elite contempt as brutally harmful, on the one hand, and a symptom of anxious dependence, on the other.

\section{II.}

Concerns about the potential of contempt for abuse pervade Wollstonecraft's earliest contribution to the education literature, the 1787 Thoughts on the Education of Daughters. In an argument particularly reminiscent of Locke, she claimed there that young society girls who have been denied the opportunity to develop virtues worthy of a dignified self-respect will compensate through a contemptuous treatment of those they consider inferior, a contempt often expressed through ridicule. Alluding, as she would do later in her attack on Burke, to Shaftesbury's claim that ridicule could test for falsehood, Wollstonecraft remarked that if ridicule lived up to its 
reputation as the 'boasted test of truth' then women should excel at increasing human knowledge (1989, IV: 13). It quickly becomes apparent, however, that Wollstonecraft had little faith in ridicule's truth-revealing capacities. On the contrary, proneness to ridicule among young women results, she regretted, in either 'trifling conversations' or the arbitrary infliction of harm on those the ridiculers deem ignorant (1989, IV: 13).

Two years later, in the Female Reader, Wollstonecraft again singled out ridicule as a particularly contemptuous (and thus abusive) form of utterance, but this time also portrayed it as the preferred weapon of dependent characters anxiously craving recognition. Under the heading 'Ridicule' she placed an excerpt from James Usher's 1767 Clio, or a Discourse on Taste which presented mockery as the refuge of those lacking in genuine self-esteem (or 'noble pride') and who mistakenly believed that they could 'rise out of contempt only by the depression of others.' By contrast, the excerpt continues, those who are 'conscious of their own superior merit $[\ldots]$ seldom affect ridicule' (1989, IV: 145). Dignified awareness of one's own self-worth, Wollstonecraft (via Usher) implied, needs no reward, least of all the recognition of others. Finally, in the Young Grandison (an educational manual by Madame de Cambon that Wollstonecraft translated from the Dutch with significant 'alterations and improvements' in 1790) Wollstonecraft again indicted ridicule as abusive while at the same time showing how a fondness for it is indicative of a misplaced sense of superiority. ${ }^{\mathrm{xv}}$ A lady who ridiculed a 'modest young gentleman who was a little deformed' (calling him a 'spider' and a 'little ape') and who 'continued to laugh' even when her victim showed signs of discomfort will eventually meet her comeuppance, Wollstonecraft grimly warned, when the 'ignorant' in turn 'laugh at her' after the physical charms that ground her self-esteem have faded. Learning to base self-esteem on virtue 
and reason, Wollstonecraft implied, would eradicate such behavior and the dependence that drives it (1989, II: 286).

What emerges from the above is that Wollstonecraft, like her predecessors in the education literature, blended a concern with the cruel incivility of contempt with a recognition that it could also be a badge of dependence, the default mode of address for those whose sense of superiority is buoyed by arbitrary differences of appearance or social status. The early 1790 s, however, saw Wollstonecraft turn her focus away from educating elites in civility and towards enumerating the specific harms done to those most frequently on the receiving end of elite contempt, such as women and the poor. No longer was such contempt merely a sign of incivility, misplaced pride, or poor education; now it emerged as an instrument of social domination in its own right. As Alan Coffee has recently shown, Wollstonecraft was highly attuned to the numerous ways in which social attitudes and customs could exercise a form of arbitrary power all of their own (2013: 118). Nowhere is this more apparent than in her attack on the custom of distributing esteem on the basis of wealth and social rank, a custom that permitted elite contempt to have devastating effects on the socially vulnerable.

Wollstonecraft's most virulent attack on this custom and the contempt it enabled arrived in chapter 9 of the Vindication of the Rights of Woman. The opening lines of the chapter made it immediately apparent that Wollstonecraft shared nothing of Hume and the early Smith's view that respecting the rich and despising the poor had any foundation in nature. Just as Smith eventually argued that the poor are despised only because of the premium society places on 'wealth and greatness,' so Wollstonecraft now claimed that contempt only flows downwards in accordance with class distinctions because of a widespread and thoroughly unnatural 'respect paid to property' (1989, V: 211). Strongly echoing Burgh's complaint that the rich in modern 
societies are adored as 'Gods upon earth,' Wollstonecraft deplored how property, 'once gained,' entitles its holders to be revered as 'demi-gods.' (1989, V: 211). Once property has been thus established as the unquestioned basis of esteem within a society, she argued, it becomes all but inevitable that the poor and women without property will draw the contempt of propertied men.

Wollstonecraft does more in this chapter, however, than merely repeat reservations voiced earlier in the education literature about the corrupting influence of contempt. Central to her analysis was that the 'undeserved contempt' to which women especially are subject can be so demeaning that its objects may become truly 'contemptible' over time (1989, V: 239). Chapone had shown that so much of elite contempt was a kind of bluster concealing (or rather revealing) a craving for recognition rather than actual superiority. Wollstonecraft's worry was that even if such contempt were groundless initially, those repeatedly forced to endure it would lose selfrespect, resulting eventually in a deformed character that is genuinely worthy of disregard. It is for this reason that Wollstonecraft herself, although often unsparing in her criticism of the foppishness and superficiality of high society women, carefully refrained from ridiculing them and warned against the dangers of doing so. ${ }^{\mathrm{xvi}}$

Awareness that the contempt suffered is undeserved, moreover, cannot shield those subjected to it from its damaging effects. There are two reasons for this, both of which are illustrated by the character of Jemima in Wollstonecraft's incomplete novel from the mid 1790s, The Wrongs of Woman, or Maria. The first is that consciousness that the contempt we suffer is ill-deserved will do nothing to prevent our standing in the eyes of society at large from being adversely affected, with real material consequences. Jemima, warden in a mental asylum and lifelong victim of poverty and abuse, finds that her sister early on 'conceived a contemptuous opinion' of her precisely because she witnessed others (especially her parents) treating her with 
contempt (1989, I: 109). An initial expression of contempt, in other words, can be contagious, and those who imitate it rarely pause to check whether the original contempt was deserved or not. Secondly, the knowledge that others feel contempt towards us can succeed in shaming us, Wollstonecraft maintained, even if we are satisfied in ourselves that we have done nothing shameful. Upon the death of her elderly benefactor, Jemima is cast out of his house by his heirs who mock her grief and accuse her of plotting to steal the deceased's property. When she subsequently asks them for wages she is owed and a character reference (vital to any future employment in late eighteenth-century Britain) she is denied on the grounds that it would be unconscionable for a lady to recommend a 'kept mistress' to anyone. Jemima knows that this affront to her reputation is unmerited but this cannot prevent her from shedding 'burning tears' of shame. For there are, she laments, 'situations in which a wretch is humbled by the contempt they are conscious they do not deserve' (1989, I: 115).

We might suspect on the basis of this evidence that Wollstonecraft saw no value in contempt whatsoever, or in the forms of speech (like ridicule) most typically used to express it. ${ }^{\text {xvii }}$ However, a critique of how it had conventionally been abused need not translate into a disavowal of contempt as such. Even setting aside for a moment her embrace of contempt in responding to Burke (to which I return below) Wollstonecraft's 1790s writings yield ample evidence that she saw value in having the dominated channel a dignified contempt of their own towards the very people or structures of power that oppressed them. By implying that those who lord it over them from a superior social vantage point are in fact beneath them according to some alternative measure of worth, the dominated could both assert their own dignity and call into question the very basis upon which social status is allocated in the first place. In this manner, 
contempt could be refashioned from a force preserving the status quo into a force for social reform.

If we look again at the Wrongs of Woman, to take a first example, we find Wollstonecraft affirming contempt as a resource for those who wish to assert their dignity in defiance of oppression. When Jemima's sympathetic listeners discuss the various deprivations unjustly suffered by the poor, Maria's lover Darnford places at the top of the list the loss of 'the independence of despising their persecutors' $(1989$, I: 116). To lose the capacity to despise or contemn one's abusers is symptomatic, Wollstonecraft here implied, of a more general loss of independence. We saw above how expressing what Chapone called 'real contempt' requires the kind of independence of character that wealth or honors (the basis of elite contempt) cannot provide. Darnford's comment reveals how the abject conditions which they are forced to endure may eventually deny the poorest members of society the independence necessary to despise those who are, at root, the cause of their suffering.

Wollstonecraft not only drew a connection between the capacity for dignified contempt and independence, however. She also explored ways in which such contempt could be actively fostered among young women, allowing them to recognize and challenge cultural narratives that legitimated the social customs that bound them as dependents to men. In chapter 13 of the Vindication of the Rights of Woman Wollstonecraft offered a preliminary sketch of what such an education in contempt might look like. Confronting the specific problem of how daughters of the gentry could be discouraged from reading 'flimsy' novels that presented women as unthinking, coquettish, and dependent on arbitrary male power, Wollstonecraft offered the following by way of advice: 


\begin{abstract}
The best method, I believe, that can be adopted to correct a fondness for novels is to ridicule them: not indiscriminately, for then it would have little effect; but, if a judicious person, with some turn for humor, would read several to a young girl, and point out both by tones, and apt comparisons [...] how foolishly and ridiculously they caricatured human nature, just opinions may be substituted instead of romantic sentiments (1989, V: 258).
\end{abstract}

This is a remarkable proposal on a number of fronts. In the first place, having expressed concern in her educational writings from the 1780s that high society women too often indulge a taste for ridicule when young, she now created a role for what is in essence a tutor in ridicule. Whether the tutor or governess responsible for other aspects of the student's education could play this role depended on whether they could combine judiciousness with a suitable 'turn for humor.' Admittedly, the ridicule in which the students were to be coached was not the personalized or abusive sort that had earlier so animated Wollstonecraft, but this endorsement of instruction in ridiculing is no less remarkable for that. Second, given the centrality of a Lockean association of ideas to her educational thought as a whole, we know that Wollstonecraft intended by this scheme to build ridiculing habits for life (1989, V: 186). ${ }^{\text {xviii }}$ If it remained the case that young women should refrain from expressing contempt towards undeserving others, it was also now evident that confrontations with stereotypes used to justify women's subordination should trigger in Wollstonecraft's students a response of disdain. ${ }^{\text {xix }}$ They were to be trained, in other words, to identify cultural products that normalize the artificial social relations so detrimental to women's freedom, and to scoff at them. 
Notwithstanding Wollstonecraft's reservations about contempt in her earlier educational writings, then, by the 1790s she was defending a form of dignified contempt that could empower young women to resist the legal, cultural, and social forces conspiring to warp their characters into servility. Notably, others in the radical London circles Wollstonecraft moved in were similarly coming to appreciate the potential for contempt to restore dignity to the dominated. In 1793 Godwin himself, while suspicious (as we have already seen) of contempt in polite conversation, also happily observed how the use of ridicule by the poor increasingly disturbed the 'tranquility' of the upper classes and inspired the ridiculers themselves with the 'consciousness of citizenship' (1793b: 40). For Godwin, reversing the usual flow of contempt by directing it against the privileged, in other words, did not have to be an empty consolation for the lower orders. It could also go some way towards redressing imbalances of social power by placing the privileged in some degree of discomfort, often, as Chapone had already shown, by simply refusing them the homage their own contempt was designed to extort. In counteracting the psychosocial effects of elite scorn, contempt itself was often the best remedy.

Grasping the full extent of Wollstonecraft's analysis of contempt, I maintain, should prompt us to reassess her chosen mode of attack on Burke. More specifically, the Vindication's opening criticism of Burke for expressing contempt from the vantage point of privilege should brace us for a treatment of him in subsequent pages as simultaneously abusive but also pitifully dependent, anxious, and even vulnerable to contempt himself. My aim in the next section is to show that this is indeed what Wollstonecraft presents us with.

III. 
Finding evidence in the Vindication of Wollstonecraft's concern with the abusive power of Burke's contempt is not especially difficult. 'Glow[ing],' as she puts it, 'with indignation,' she indicts Burke repeatedly for casting down 'thundering censures' and the 'bushfiring of ridicule' upon those less privileged than himself, not least Richard Price, who had been a close friend and mentor to Wollstonecraft during her time managing a school at Newington Green (1989, V: 7 and 40). ${ }^{\mathrm{xx}}$ Indignation, however, fuels only a portion of Wollstonecraft's response to Burke. As Martha Nussbaum has argued, indignation, because provoked by some identifiable act of harm, usually prompts protests against, or attempts to reform, the afflicter of the harm. More visceral emotional reactions like disgust, by contrast, want simply 'to get the person out of sight' (2004: 106). We have already seen that contempt, as Wollstonecraft's contemporaries conceived of it, manifested itself as a desire to place considerable distance between oneself and whatever one finds contemptible. When Wollstonecraft announces to Burke that his ridicules of Price have earned her contempt, we should expect nothing else than that she will regard Burke thereafter as unworthy of engagement and pass over much of what he wrote as not worth her attention (1989, $\mathrm{V}: 44)$. True to that initial promise, Wollstonecraft time and again sidesteps substantial engagement with the details of Burke's arguments and does so unapologetically.

Readers of the Vindication are treated to an example of such a deliberate withholding of attention in the very first sentence. Wollstonecraft, again making her intention explicit, dispenses with the marks of respect usually prefaced to replies of this sort, especially from authors of a social standing inferior to that of the addressee. She will not, she tells Burke, apologize for 'intruding' on his 'precious time' (1989, V: 7). Nor will she declare that it is 'an honor' to discuss the rights of man with someone of Burke's literary abilities. Her opening sally then, is not an indignant complaint, but a calm withholding of pleasantries conventionally due on such 
occasions. The refusal of honorifics, however, has only just begun. Even after such an opening, Wollstonecraft's readers might still have expected her to refute the 'specious' arguments from Burke that roused her 'indignation' in the first place (1989, V: 5). But they would be largely disappointed. In spite of the damage his arguments have wrought in her eyes, she ultimately concludes that it would be too 'tedious' to try her own patience and that of her readers by pointing out their flaws (1989, V: 59).

It this precisely this strategy of evasion that has so frustrated critics of the Vindication then and since. ${ }^{\mathrm{xxi}}$ It is a strategy, however, that Wollstonecraft amply justified over the course of the text. The Vindication, I maintain, contains a coherent argument as to why most members of the upper classes should be denied the esteem they so anxiously crave by those beneath them socially. So long as the prevailing system of unnatural social distinctions persists, Wollstonecraft argued, the middle class in particular will have prima facie grounds for regarding themselves as superior in dignity to, rather than the mere equals of, the rich. The Vindication, we will see, served not only as an example of how propertied elites can be treated with contempt by a social inferior, but also presented a case for why they usually should be. In other words, Wollstonecraft attempted more than merely cutting Burke down to size; she argued for a wholesale rethinking of the manner in which contempt should be distributed in a class-based society. ${ }^{x x i i}$

Upon what grounds did she so argue? As with so many of Wollstonecraft's arguments, this one concerned education (broadly conceived as the set of environmental factors that contribute to a person's moral and intellectual development). At its core was the following claim: the pampered upbringing enjoyed by the rich actually deprives them of sufficient opportunities to develop the capacities necessary for a rational exchange between citizens on matters of public importance. In this respect, the very rich and very poor have something in common. The social 
conditions of both groups (debasing physical labor for the one and complete lack of material want for the other) have conspired to deny them an education adequate to the demands of a free society and left them in a state of dependence. Yet in spite of the fact that both groups are dependent, only the poor routinely experience contempt. The deference granted as a matter of course to the rich allows them to overlook their own debility and artificially props up their selfesteem. By continuing to revere the rich in this manner, Wollstonecraft claimed, her contemporaries reinforced wealth as an artificial basis of social esteem, contributed to the further debasement of the most vulnerable in society, and lent overall legitimacy to a corrupt social order.

It is this argument that propelled Wollstonecraft's insistence, early in the Vindication, that the category of the 'vulgar' (a term Burke regularly deployed in the Reflections to describe the poor or uneducated) be expanded to include the rich. '[B]y this epithet,' she declared, 'I mean not only to describe a class of people, who, working to support the body, have not had time to cultivate their minds' but 'likewise those who, born in the lap of affluence, have never had their invention sharpened by necessity' and so become 'creatures of habit and impulse' (1989, V: 16). Poverty and affluence, Wollstonecraft here claimed, each work to mould individuals into dependence, albeit by different means. Later in the Vindication she reiterated the claim. Taking Burke to task for deriding the women who marched on Versailles as 'furies of hell' while reserving pity for Marie Antoinette, she again established a surprising equivalence between poverty and privilege where most would have seen only difference. The 'great and small vulgar' have equal claim on 'our pity,' she wrote, because both have 'insuperable obstacles to surmount in their progress towards true dignity of character' (1989, V: 30). The obstacles confronting the rich may be less obvious, Wollstonecraft suggested, but they are no less formidable for that. 'Is it 
among the list of possibilities,' she rhetorically asked, 'that a man of rank and fortune can have received a good education' when his 'wants are instantly supplied' and (repeating a phrase from earlier) his ‘invention is never sharpened by necessity’ (1989, V: 42)? For Wollstonecraft, to be granted everything at a young age is in the long run to be denied much, including the chance to develop the 'true dignity' needed to inoculate against contempt.

The dependence that causes the rich to later express contempt as a way to paper over their insecurities is thus bred into them from the very beginning. In making this claim Wollstonecraft sided with her predecessors in the education literature who had insisted that elite contempt was an acquired vice rather a reflection of a natural human tendency to admire wealth and scorn poverty. Unlike them, however, she voiced skepticism as to whether early tutoring in civility and self-restraint could offset the debilitating effects of entrenched privilege. The 'tutors and chaplains' entrusted with the education of noble children command such little respect, she maintained, that they more closely resemble 'jesters' serving as a 'whetstone for the blunt wit of the noble peer who patronizes them' $(1989, \mathrm{~V}: 38)$. Because they themselves are usually beholden to a system of patronage spawned by the division of classes, most tutors cannot be relied upon to educate their charges into independence and dignity. The result is a class of dependent and undignified people, anxiously seeking acknowledgement of their spurious claims to superior status.

By recasting an upbringing in a wealthy home as both a privilege and a disadvantage from which it is extremely difficult to recover, Wollstonecraft thus made a case in the Vindication for treating the rich, not with the signs of homage to which they accustomed, but rather with the same kind of 'pity bordering on contempt' that she poured down on Burke. ${ }^{\text {xxii }}$ It was a case she would make again two years later when composing the Vindication of the Rights 
of Woman. The 'middle classes,' she there argued, 'appear to be in the most natural state.' They have been spared both the debilitating effect of poverty and the enfeebling effects of wealth. The 'great' by contrast, 'have the strongest claim to pity' (1989, V: 75). Denied the chance to 'practice the duties which dignify the human character' they are left 'vain and helpless' (1989, V: 75). Consequently, Wollstonecraft proposed adopting 'a separate view of the different ranks of society' rather than pretending that characters produced by each will possess equal dignity (1989, V: 75).

There is, then, an argumentative thread concerning the appropriate manner of regarding the idle rich that runs from one Vindication to the next. Over the course of the two works, Wollstonecraft built a case for treating those rich not as, at base, similar to the rest of society, but as fundamentally deprived by their upbringing of a dignity that lies within reach of the majority. As such, far from being entitled to the esteem they lay claim to, the rich are deserving of the very same disregard they normally exhibit towards the poor and vulnerable. Once this argument is borne in mind, then Wollstonecraft's attack on Burke appears less like an intemperate outburst than an exemplary mode of address that she wished others to imitate.

It might immediately be objected that if Wollstonecraft had wanted to justify contempt towards an idle upper class incapacitated by their pampered upbringings, then she could have chosen a better target than Edmund Burke. As she herself concedes, Burke was born without title and his rise to prominence was achieved largely on merit. ${ }^{\text {xiv }}$ This, in Wollstonecraft's eyes, however, only made his defection to the side of property all the more troubling. Burke had made that defection explicit in the Reflections, urging that possession of landed property be retained as the primary basis for the distribution of esteem within English society over and against the claims of ability. Against the Marquis de Barentin's proclamation at the opening of the Estates 
General that 'all occupations were honorable,' Burke bluntly retorted that the 'occupation of an hair-dresser' or a 'working tallow-chandler' simply 'cannot be a matter of honor to any person' (1993: 49). To suggest otherwise was not to challenge a 'prejudice' but to 'war with nature' itself (1993: 49). Burke's immediate rhetorical purpose in these lines was to subject arguments for equal rights to a reductio ad absurdum: to press for political equality is to press eventually for even those in the lowliest of occupations to take up the reins of government. But though he would later clarify that he did not wish to exclusively 'confine power, authority and distinction to blood, and names, and titles, 'Burke continued in the Reflections to weigh in heavily on the side of property against what he called the 'invasion of ability' (1993: 50-51). Thus even if Burke had not been born into the idle upper class, Wollstonecraft had reason to believe he had opted to make himself a tool of it. When she accused Burke of lacking 'enlightened self-love' she meant precisely that he had lost the self-esteem that came from living a dignified, independent existence $(1989, \mathrm{~V}: 34)$. Having embraced the dependence that came from being at or near the apex of a corrupt social order, Wollstonecraft maintained, Burke could no longer be expected to reason as an equal. Indeed, it would be 'cowardice' to oblige him to do so (1989, V: 10).

IV.

The audacity and even ferocity of the Vindication of the Rights of Men should not blind us to the fact that it contains arguments. One of those arguments, I have contended, concerns how contempt should ideally be apportioned in the England of Wollstonecraft's day and on what basis. Macalester Bell has recently claimed that 'a society completely lacking status distinctions' would be one in which 'contempt could not exist' (2013: 38). Wollstonecraft saw no such society on the horizon in the 1790s. Her affirmation of contempt in confronting Burke suggests that her 
vision of an egalitarian social order allowed considerable room for legitimate claims to higher dignity or status. This, however, begs the wider question of what kind of status distinctions should persist in a society committed to equality. If, as many political theorists have argued, recognition of equal dignity is foundational to modern democracy, then we might well ask whether a passion like contempt that thrives upon status distinctions should not be dismissed as an unfortunate remnant of a more hierarchical social order. ${ }^{\mathrm{xxv}}$ To defend equal dignity, in other words, must we do away with contempt entirely? In closing, I draw on Wollstonecraft's analysis to address this difficulty head-on and explain how contempt can be re-imagined as a democratic virtue rather than an aristocratic vice.

To answer the charge that contempt is inimical to democratic aspirations we need first recall that not all status distinctions threaten the kind of dignity necessary to sustain democracy. A society free of the degrading behaviors that sap the independence needed for citizenship may still allow, or even encourage, contests over dignity. Josiah Ober has recently shown that 'civic dignity' (understood as 'equal high standing among citizens') is compatible with significant competition for status based on merit or excellence (2012: 829). ${ }^{\mathrm{xxvi}}$ Pushing this claim still further, he argues that if heroic public actions that protect the dignity of all citizens can win public acclaim then intense status contests among prominent citizens may even support civic dignity. Overlooked by Ober, however, is that citizens suffering various forms of domination and thus prevented from performing such prestigious public actions - may still contribute to a more democratic order by expressing contempt for those who are well positioned to support civic dignity but who instead lord it over their social inferiors, much as Wollstonecraft accused Burke of doing. In other words, while Ober is correct that democracy is strengthened when citizens applaud those who uphold civic dignity, Wollstonecraft showed how it can also gain 
from citizens who regard with contempt those whose who actively undermine that dignity by humiliating those beneath them.

Even if we concede, however, that the kind of contempt Wollstonecraft showed towards Burke is a legitimate response to those who menace civic dignity, it might still be objected that the risks posed to civility by contempt remain too formidable for us to endorse it without misgivings. 'Mutual contempt,' as Teresa Bejan and Bryan Garsten have rightly noted, 'can corrode the affective bonds of democratic citizenship' (2014: 18). Indeed, it would be difficult to describe as democratic any society in which citizens routinely demeaned one another or refused to at least formally recognize each other as equals. Before rushing to impeach contempt as such, however, Wollstonecraft reminds us to take stock of who is being harmed by contempt in any given instance. There is a danger, her analysis suggests, in treating all expressions of contempt as equally objectionable. If we acknowledge, for instance, that contempt for the socially marginalized can compound their subjection by undercutting their capacity for independence, then we need to treat this as a qualitatively different kind of injury than any contempt the privileged might suffer. A blanket appeal for citizens to withhold expressing contempt could smother these crucial differences.

More important still, Wollstonecraft's analysis helps us see how expressions of contempt are always reflections of deeper economies of value. Before asking what kinds of slanders, defamations, ridicules or slurs qualify as civil and which do not, we might instead interrogate the set of goods possession of which nearly always guarantee members of a society the esteem of their peers. In a society in which wealth is treated as a mark of prestige, formal equality under the law or even a wide commitment to civility will not prevent contempt from being directed towards the materially deprived. If Hume was correct that contempt forms on the basis of a 
comparison between ourselves and others then something has to serve as the basis of that comparison. Wollstonecraft stressed the need for us to continually evaluate the true worth of whatever that esteem-conferring good might be. And even if Smith was right that, in commercial societies at least, displacing wealth as the principal font of esteem will prove next to impossible, expressing contempt for those rich who either fail to uphold or deliberately undermine civic dignity may be one way to signal that the dominance of wealth over our esteem need not be total.

Finally, Wollstonecraft suggests a surprising connection between contempt and the character traits necessary for citizens to strive for freedom from domination. Recent scholarship has rightly sought to fold Wollstonecraft's Vindications into a republican tradition that conceptualizes freedom as non-domination and independence from arbitrary power. ${ }^{\text {xxvii }}$ Less examined in that literature, however, have been the specific resources Wollstonecraft offered for resisting domination and establishing the social conditions in which freedom may be enjoyed. Wollstonecraft's educational program for young girls suggests that a training in contempt may enable the oppressed to better recognize (and defy) the forces that render them vulnerable to domination in the first place. That this has been overlooked may in part be due to Wollstonecraft's own success in exposing the ways in which contempt more often than not facilitated domination by (especially) the socially privileged. Once we come to better appreciate the multiple forms that contempt can take, however, then it becomes apparent that those who have been debased by contempt may be the same people who stand to gain most from learning to exercise it themselves against their oppressors.

Note that such an education in contempt need not entail stoking class antagonisms. The dignified contempt that Wollstonecraft espoused is not hatred; nor is it resentment. Both of these passions are typically responses to an injury or specific harm, and both can have debilitating 
effects on whoever is in the grip of them. Contempt, on the other hand, need not be reactive and can instead be nurtured as a settled disposition derived from a consciousness of one's own superior dignity with regard to some compromised other. ${ }^{\text {xxviii }}$ Wollstonecraft was moved to anger by Burke's harsh treatment of Richard Price. Her contempt, however, was reserved for the idle rich more generally and stemmed from a considered view that neither wealth nor blood should serve as the dominant basis of respect in a civilized society. It was a contempt she was harshly judged for when she first expressed it. Her vindication is long overdue.

\section{Acknowledgements}

The author would like to thank the following for their extremely helpful remarks on earlier drafts of this article: Teresa Bejan, Aurelian Craiutu, John Lombardini, Celeste McNamara, Adam Potkay, Rebekah Sterling, Doug Thompson, Terah Walkup, John Zumbrunnen, two anonymous EJPT reviewers, and the EJPT Editors. The article also benefitted enormously from audiences at the 2014 Association for Political Theory Conference in Madison, the William \& Mary Government Department Colloquium, and the Georgetown Political Theory Workshop.

\section{Notes}

${ }^{i}$ All Wollstonecraft references (unless stated otherwise) are to Janet Todd and Marliyn Butler's 1989 seven volume The Works of Mary Wollstonecraft. Volume numbers are included as roman numerals in the parentheses followed by the relevant page number.

ii Wollstonecraft reprimands Burke twice for treating Price with contempt (1989, V:18 and 44), twice for the contempt he shows towards the poor (1989, V: 21 and 55) and once for his treatment of the Assemble Nationale deputies (1989, V: 40).

iii The argument that recourse to ridicule is a poor substitute for argument recurs throughout Wollstonecraft's corpus. See for instance her criticism, in her Historical and Moral View of the French Revolution, of the French habit of using 'sharpened wit' to counter arguments 'with which they have not strength fairly to wrestle' (1989, VI: 228).

${ }^{\text {iv }}$ On the 'wry sense of humor' that pervades Wollstonecraft's writings see Botting (2014: 262).

' In his Defense of the Rockingham Party, Godwin expressed disagreement with Burke's 'aristocratic principles' but went out of his way not to 'question the integrity of any man, upon account of his tenets, whether in religion or politics' (1783: 30). He even expressed concern that Burke had been the victim of 'superficial raillery and abuse' (1783: 35). The contrast with Wollstonecraft's approach to Burke could hardly be starker.

${ }^{v i}$ Ralph Wardle maintained that Wollstonecraft subjected Burke to 'sheer abuse' rather than arguing with him (1951: 118). Virginia Sapiro similarly saw 'haste' and 'anger' in Wollstonecraft's rhetorical choices (1992: 201). Not everyone, however, has taken issue with Wollstonecraft's tone. Amartya Sen has praised Wollstonecraft for her 'quite remarkable' way of 'combining wrath and reasoning in the same work' (2009: 392). I share Sen's admiration but disagree that 'wrath' is the only or even predominant passion on display in Wollstonecraft's Vindications.

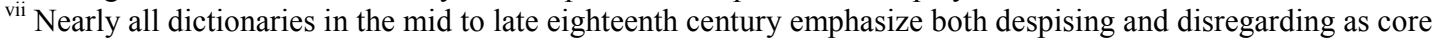
ingredients in contempt. Johnson's Dictionary of 1755 defined the verb 'contemn' as 'to despise, to scorn, to slight, to disregard, to neglect to defy' and equated contempt with 'the act of despising' (1755). John Ash's New and Complete Dictionary of 1775 followed suit by including 'despise' and 'neglect' in the definition of contempt (1775).

${ }^{v i i i}$ Although Don Herzog has shown that because there are many 'different dimensions along which one might qualify as high' contempt was 'a furiously contested battleground' (2000: xiii and 189). 
ix I take the term 'active non-identification' from Bell (2013: 53),

${ }^{\mathrm{x}}$ For a defense of civic dignity as a cardinal value of democracy see Ober (2012).

${ }^{x i}$ On Wollstonecraft and Scottish Enlightenment philosophy see O’Neill (2007).

xii At I.3.2 Smith hints that our 'state of deference' towards the rich is merely 'habitual,' while in the same paragraph referring to our 'natural disposition to respect them' (2002: 64).

xiii On Wollstonecraft's fraught relationship with these literatures see Jones (2002).

${ }^{\text {xiv }}$ Wollstonecraft selected numerous passages from Chapone's 1773 Letters on the Improvement of the Mind when compiling her Female Reader, a compendium of 'Miscellaneous Pieces, in Prose and Verse' chosen 'from the Best Writers for the Improvement of Young Women' (1989, IV: 53). More telling still, Wollstonecraft exempted Chapone from some of the more scathing criticisms she leveled against female educational theorists in chapter 5 of the Vindication of the Rights of Woman, a chapter devoted to censuring 'writers who have rendered women objects of pity, bordering on contempt.' While Wollstonecraft saw most educational manuals as complicit in the degrading of women, Chapone's Letters, she there remarks, 'contain so many useful observations that I only mention them to pay the worthy writer this tribute of respect,' a remarkable endorsement given the generally critical tone of this portion of the Vindication (1989, V:147 and 174).

${ }^{x v}$ Wollstonecraft's translations can safely be read as expressing her own views. As Sylvana Tomaselli writes: 'the texts she produced were as if her own, not just because she agreed with the ideas put forward, but because she more or less re-wrote their contents' (2012: 237).

${ }^{\mathrm{xvi}}$ Throughout the Vindication of the Rights of Woman Wollstonecraft held firm to the conviction that even women who surrender their independence through an unhealthy 'attachment to rakes' should not be 'satirized' on the basis of faults that are the result of their education (1989, V: 118). See also chapter 13, Section III, where Wollstonecraft warns that to 'laugh at [...] or satirize the follies of a being who is never allowed to act freely from the light of her own reason is as absurd as cruel' (1989, V: 260).

xvii On the use of ridicule by elites to cow social inferiors in the eighteenth century see Dickie (2011: chapter 5).

${ }^{x v i i i}$ Commenting on this passage Saba Bahar notes that the students would in time 'internalise this authoritative counsel and ridicule' (2002: 115).

${ }^{x i x}$ For the importance of association to Wollstonecraft's educational outlook see chapter 6 of the Vindication of the Rights of Woman.

${ }_{\mathrm{xx}}$ Towards Price, Wollstonecraft seethed, Burke was a bully, showing no qualms about subjecting an ageing minister then 'tottering on the verge of the grave,' to 'willful' and 'wanton abuse' (1989, V: 18-19).

${ }^{\mathrm{xxi}}$ An anonymous reviewer complained that from Wollstonecraft's title page 'we expected this work would have been confined to an examination of Mr Burke's political principles. This, however, occupies but a small part of the whole' (1791b: 96).

xxii Miller has coined the phrase 'upward contempt' to describe the contempt shown by those lower on the social spectrum towards their social superiors (1995: 476).

xxiii This phrase occurs in the title of chapter 5 of the Vindication of the Rights of Woman.

${ }^{\text {xxiv }}$ Whereas most gain prominence through 'fortune and hereditary office,' Wollstonecraft writes, 'you [Burke] have raised yourself by exertion and abilities' (1989, V: 43).

${ }^{\mathrm{xxv}}$ George Kateb in particular has insisted that what he calls the 'existential' value of human dignity must be central to any robust defense of human rights (2014: 10).

xxvi Ober draws heavily on Jeremy Waldron's argument that the high standing conveyed by the word dignity has now been extended (at least in theory) from aristocrats to all members of society (Waldron, 2012).

${ }_{\text {xxvii }}$ On Wollstonecraft's republican understanding of freedom see Coffee (2013) and Halldenius (2007: 80-84).

${ }^{\text {xxviii }}$ Asserting one's dignity need not always be an expression of independence or freedom. As Michael Rosen has pointed out, in Catholic thought in particular the poor were recognized as having their own dignity, but it was a dignity they possessed by virtue of occupying a place in a 'properly ordered hierarchy' (2012: 18).

\section{References}

Anon. (1791a) Review of Vindication of the Rights of Men. The English Review, or an Abstract of English and Foreign Literature 17. London: printed for J. Murray.

Anon. (1791b) Review of Vindication of the Rights of Men. The Monthly Review; or Literary Journal, enlarged from January to April 4. London: Printed for R. Griffiths.

Ash, J (1775) New and Complete Dictionary. London: printed for Edward and Charles Dilly. Bahar S (2002) Mary Wollstonecraft's Social and Aesthetic Philosophy. New York: Palgrave. 
Bejan T and Garsten B (2014) The Difficult Work of Liberal Civility. In Sarat A (ed.) Civility, Legality and Justice in America. Cambridge: Cambridge University Press.

Bell M (2013) Hard Feelings: The Moral Psychology of Contempt. Oxford: Oxford University Press.

Burgh J (1749) Thoughts on Education. Boston: Reprinted and sold by Rogers and Fowle.

Burke E; Mitchell LG (ed.) (1993) Reflections on the Revolution in France. Oxford: Oxford University Press.

Chapone H (1786) Letters on the Improvement of the Mind. London: Printed for J. Walter.

Coffee A (2013) Mary Wollstonecraft, freedom and the enduring power of social domination. European Journal of Political Theory 12 (2): 116-135.

Dickie S (2011) Cruelty and Laughter: Forgotten Comic Literature and the Unsentimental Eighteenth Century. Chicago: University of Chicago Press.

Godwin W (1783) A Defense of the Rockingham Party. London: printed for J. Stockdale.

Godwin W (1793a) The enquirer. Reflections on education, manners, and literature. In a series of essays. Philadelphia: printed for Robert Campbell \& Co by John Bioren.

Godwin W (1793b) An enquiry concerning political justice, and its influence on general virtue and happiness. Dublin: printed for Luke White.

Godwin W (1798) Memoirs of the Author of the Vindication of the Rights of Woman. London: printed for J. Johnson.

Halldenius L (2007) The Primacy of Right. On the Triad of Liberty, Equality, and Virtue in Wollstonecraft's Political Thought. British Journal for the History of Philosophy 15 (1): 75-99.

Herzog D (2000) Poisoning the Minds of the Lower Orders. Princeton: Princeton University Press.

Hobbes T; Molesworth W (ed.) (1840) The English Works of Thomas Hobbes of Malmesbury 11 vols. London: John Bohn.

Hobbes T; Richard Tuck ed. (1991) Leviathan. Cambridge: Cambridge University Press.

Hume D; Mary K. Norton and David Fate Norton (eds) (2003) A Treatise of Human Nature vol. I. Oxford: Clarendon Press.

Hunt Botting E (2014) The Personal is the Political: Wollstonecraft's Witty, First Person Feminist Voice. In Eileen Hunt Botting (ed.) The Vindication of the Rights of Woman. New Haven: Yale University Press.

Johnson S (1755) A dictionary of the English language: in which the words are deduced from their originals, and illustrated in their different significations, by examples from the best writers, to which are prefixed a history of the language, and an English grammar. London : Printed by W. Strahan, for J. and P. Knapton; T. and T. Longman; C. Hitch and L. Hawes; A. Millar; and R. and J. Dodsley.

Jones V (2002) Mary Wollstonecraft and the Literature of Advice and Instruction. In Johnson C (ed.) The Cambridge Companion to Mary Wollstonecraft. Cambridge: Cambridge University Press.

Kateb G (2014) Human Dignity. Cambridge, MA: Belknap.

Locke J; Tarcov N (ed.) (1996) Some Thoughts Concerning Education. Indianapolis, IN: Hackett.

Miller W (1995) Upward Contempt. Political Theory 23 (3): 476-499.

Nussbaum M (2004) Hiding from Humanity: Disgust, Shame, and the Law. Princeton, NJ: Princeton University Press.

Ober J (2012) Democracy's Dignity. American Political Science Review 106 (4): 827-846.

O'Neill, D (2007) The Burke-Wollstonecraft Debate: Savagery, Civilization and Democracy. University Park, PA: Penn State University Press.

Rosen M (2012) Dignity: Its History and Meaning. Cambridge, MA: Harvard University Press.

Sapiro V (1992) A Vindication of Political Virtue: the Political Theory of Mary Wollstonecraft. Chicago: Chicago University Press.

Sen A (2009) The Idea of Justice. Cambridge, MA.: Harvard University Press.

Smith A; Haakonsen K ed. (2002) The Theory of Moral Sentiments. Cambridge: Cambridge University Press.

Tomaselli S (2012) Mary Wollstonecraft: the reunification of the domestic and political spheres. In Heinz M and Doyé S (eds.) Geschlechterordnung und Staat: Legitimationsfiguren der politischen Philosophie (16001850). Berlin: Oldenbourg.

Waldron J (2012) Dignity, Rank, and Rights. Oxford: Oxford University Press.

Wardle R (1951) Mary Wollstonecraft: A Critical Biography. Lawrence, KS: University of Kansas Press.

Wollstonecraft M; Todd T and Butler M (eds.) (1989) The Works of Mary Wollstonecraft, 7 vols. New York: New York University Press. 
Wollstonecraft, M; Janet Todd (ed.) (1993) A Vindication of the Rights of Woman and A Vindication of the Rights of Men. Oxford: Oxford University Press. 